\title{
Validation of an HPLC Method for the Simultaneous Quantification of Metabolic Reaction Products Catalysed by CYP2E1 Enzyme Activity: Inhibitory Effect of Cytochrome P450 Enzyme CYP2E1 by Salicylic Acid in Rat Liver Microsomes
}

\author{
Hassan Salhab*(D), Declan P. Naughton and James Barker ${ }^{\mathbb{D}}$ \\ School of Life Sciences, Pharmacy and Chemistry, Kingston University, Kingston-upon-Thames, \\ London KT1 2EE, UK; d.naughton@kingston.ac.uk (D.P.N.); j.barker@kingston.ac.uk (J.B.) \\ * Correspondence: K1542808@kingston.ac.uk; Tel.: +44-7984974741; Fax: +44-208-4179000
}

Received: 18 December 2019; Accepted: 17 February 2020; Published: 19 February 2020

\begin{abstract}
Inhibition of cytochrome P450 (CYP) alters the pharmacokinetic parameters of the drug and causes drug-drug interactions. Salicylic acid been used for the treatment of colorectal cancer (CRC) and chemoprevention in recent decades. Thus, the aim of this study was to examine the in vitro inhibitory effect of salicylic acid on CYP2E1 activity in rat liver microsomes (RLMs) using high-performance liquid chromatography (HPLC). High-performance liquid chromatography analysis of a CYP2E1 assay was developed on a reversed phase $\mathrm{C}_{18}$ column (SUPELCO $25 \mathrm{~cm} \times 4.6 \mathrm{~mm} \times$ $5 \mu \mathrm{m})$ at $282 \mathrm{~nm}$ using $60 \% \mathrm{H}_{2} \mathrm{O}, 25 \%$ acetonitrile, and $15 \%$ methanol as mobile phase. The CYP2E1 assay showed a good linearity $\left(\mathrm{R}^{2}>0.999\right)$, good reproducibility, intra- and inter-day precision $(<15 \%)$, acceptable recovery and accuracy $(80-120 \%)$, and low detection $(4.972 \mu \mathrm{M}$ and $1.997 \mu \mathrm{M})$ and quantitation limit values $(15.068 \mu \mathrm{M}$ and $6.052 \mu \mathrm{M})$, for chlorzoxazone and 6-hydroxychlorzoxazone, respectively. Salicylic acid acts as a mixed inhibitor (competitive and non-competitive inhibition), with $\mathrm{K}_{\mathrm{i}}$ (inhibition constant) $=83.56 \pm 2.730 \mu \mathrm{M}$ and concentration of inhibitor causing $50 \%$ inhibition of original enzyme activity $\left(\mathrm{IC}_{50}\right)$ exceeding $100 \mu \mathrm{M}\left(\mathrm{IC}_{50}=167.12 \pm 5.460 \mu \mathrm{M}\right)$ for CYP2E1 enzyme activity. Salicylic acid in rats would have both low and high potential to cause toxicity and drug interactions with other drugs that are substrates for CYP2E1.
\end{abstract}

Keywords: salicylic acid; rat liver microsomes; CYP2E1 activity; cytochrome P450; mixed inhibitor

\section{Introduction}

Members of the cytochrome P450 (CP450) superfamily are known as phase 1 enzymes and play a key role in the biotransformation of a large number of endogenous (steroids, hormones, bile acids, fatty acids) and exogenous (toxic chemicals, drugs, carcinogens, environmental pollutants) compounds to a more hydrophilic form [1]. Statistical results showed that more than $90 \%$ of marketed drugs are metabolized by P450s [2]. However, with more than 10 forms identified, only the CYP1, CYP2, and CYP3 families are involved in the biotransformation of the majority of clinical drugs [2].

Because P450s play a vital role in drug metabolism, co-administration of a drug with another CYP substrate may alter their metabolism, thus causing a drug-drug interaction [2]. As a definition, drug interactions take place when a certain drug interacts with another drug [3]. These interactions can result in the changing activity of one or both drugs and lead to adverse side effects [4]. Statistical evidence has shown that nearly $20-40 \%$ of elderly people in developing countries have drug-drug interactions due to poly-therapy [5]. 
Understanding the properties of adverse drug reactions (ADRs) gives us a clear indication for quantification of the side effects of a prospective drug and a good knowledge of the pathogenic pathways involved during the interaction [5]. Nowadays, adverse drug reactions seem to be the main obstacle in clinical trials, slowing down the recovery of patients in hospitals [5].

It has been reported by Badyal and Dadhich (2001) that drug-drug interactions could be the fourth or the sixth leading cause of deaths in United States. Drug-drug interactions can be the result of inhibition and induction of P450 enzyme activity [3]. Potential drug-drug interactions appear to be the most challenging part of clinical practice, resulting in pharmacokinetic and pharmacodynamic variations of the drugs and changing their overall therapeutic response [6]. On the contrary, a clear understanding in both drug metabolism and drug interaction has resulted from allotting P450 enzymes based on their amino acid chain [7]. Many drugs have been withdrawn from U.S. market, e.g., terfenadine, astemizole, and cisapride, because the inhibition of these drugs by other drugs results in arrhythmias [8].

Relevant studies have suggested that potential drug-drug interactions (pDDIs) are more likely to occur in persons suffering from cardiovascular disease compared to other major diseases [6]. The explanation for this clinical observation can refer primarily to many factors such as age, combination therapy, and the effective therapeutic management of drugs used in cardiology [6]. In fact, mibefradil, a calcium channel blocker, was withdrawn from U.S. market since it acts as a potent inhibitor that increases the toxicity level of certain cardiovascular drugs [8]. Specific enzyme activity and metabolite formation can be predicted.

Aspirin (acetyl salicylic acid) is a nonsteroidal, anti-inflammatory drug used for the treatment of fever, pain, and inflammation [9]. It is hydrolysed to salicylic acid in the liver, intestine, and plasma by means of the esterase enzyme [9]. Salicylic acid (Figure 1) is a natural compound obtained from wintergreen leaves and white willow trees, and possesses many beneficial pharmacological activities, such as anti-inflammatory, antioxidant, and vasodilator effects [9]. It has been reported by Danchineni (2017) that salicylic acid potentially targets tumour cells by downregulating the function of cyclin A2, B1, D3, and cyclin-dependent kinases (CDKs 1,2,4, and 6) to exert a chemopreventive effect. Recently, inhibition studies demonstrated that CYP2E1 enzyme is responsible for the hydroxylation of salicylic acid in humans [9].

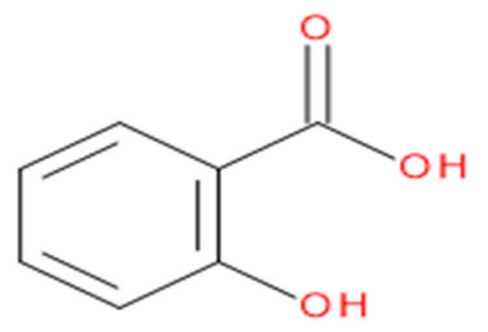

Figure 1. Chemical structure of salicylic acid.

However, there is a lack of information concerning the effect of salicylic acid on other CYPs. There is thus an urgent need for a detailed study on the inhibitory effect of salicylic acid on other P450s enzyme activities. Our previous in vitro inhibition study showed that salicylic acid acts as a non-competitive inhibitor for CYP2C11 enzyme activity [10]. This means that salicylic acid has a low potency to cause drug interactions with other drugs that are substrates for the CYP2C11 enzyme.

The aim of this study is to investigate the inhibitory effect of salicylic acid on the metabolism of the CYP2E1 isoform in male rat liver microsomes. In this systematic study, the in vitro inhibitory effect of salicylic acid on CYP2E1 enzyme activity was evaluated to determine the potency of salicylic acid in affecting CYP mediated phase 1 metabolism in male rat microsomes, employing chlorzoxazone as a probe substrate for the CYP2E1 enzyme in the presence of different concentrations of salicylic acid. 


\section{Results and Discussion}

\subsection{Selection of Analytical Wavelength: UV-VIS SPECTROSCOPY (CYP2E1 Assay)}

UV-VIS spectrophotometry analysis for CYP2E1 assay was carried out by dissolving chlorzoxazone $(200 \mu \mathrm{M})$, phenacetin $(50 \mu \mathrm{M})$, salicylic acid $(100 \mu \mathrm{M})$, and 6-hydroxychlorzoxazone $(50 \mu \mathrm{M})$ powder in pure acetonitrile (wavelength cut-off is $210 \mathrm{~nm}$ ) [11].

The following figure demonstrates the measurements of maximum wavelength of each compound in the CYP2E1 assay.

According to the overlain spectra (Figure 2), it is perceived that the maximum of the absorption band for the four components in CYP2E1 assay is $282 \mathrm{~nm}$.

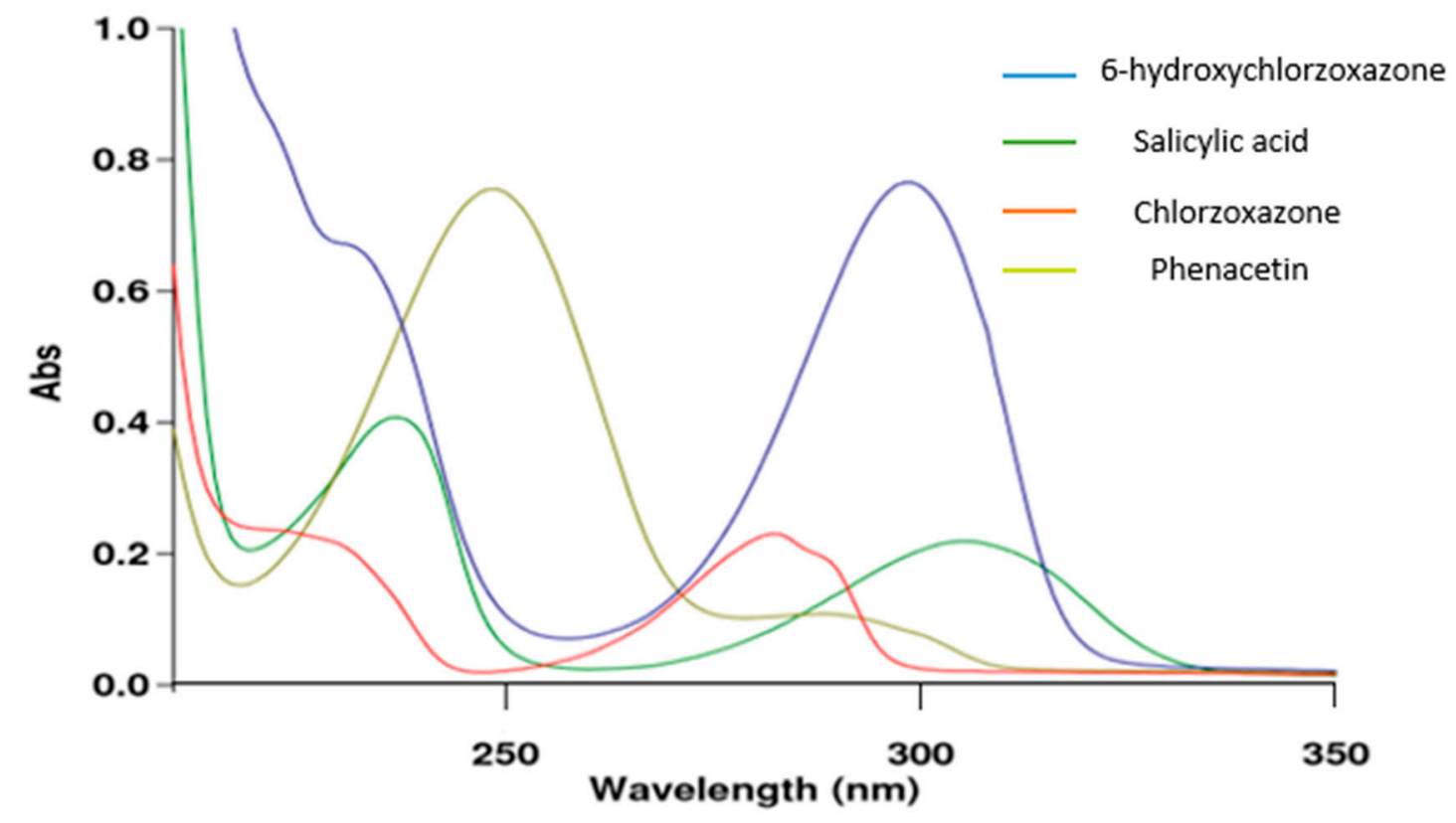

Figure 2. Overlain spectra of each component in the cytochrome P2E1 (CYP2E1) assay.

\subsection{Method Development (CYP2E1 Assay):}

Method development for CYP2E1 assay was assessed using HPLC low-pressure isocratic elution programming $\left(60 \% \mathrm{H}_{2} \mathrm{O}, 15 \%\right.$ methanol, and $25 \%$ acetonitrile $)(\lambda=282 \mathrm{~nm}$, flow rate $=0.7 \mathrm{~mL} / \mathrm{min}$, $\mathrm{T}=25^{\circ} \mathrm{C}$ ) (see Appendix A).

\subsection{Validation of the Analytical Chromatographic Method (CYP2E1 Assay):}

\subsubsection{Specificity and Selectivity}

Specificity was achieved by choosing the right mobile phase composition $\left(60 \% \mathrm{H}_{2} \mathrm{O}, 25 \%\right.$ acetonitrile, and 15\% methanol). It results in a good separation of the salicylic acid peak from the CYP2E1 metabolite (6-hydroxychlorzoxazone) peak at $\mathrm{T}=25^{\circ} \mathrm{C}$ using C18 (SUPELCO $25 \mathrm{~cm} \times 4.6 \mathrm{~mm}$, $5 \mu \mathrm{m})$, at a $0.7 \mathrm{~mL} / \mathrm{min}$ flow rate and wavelength of $\lambda=282 \mathrm{~nm}$. In order to determine the retention time of each compound in the CYP2E1 assay, each compound was run separately using phenacetin as an internal standard on the HPLC instrument using isocratic elution programming.

Figure 3 shows the chromatogram of the response peaks of four compounds (salicylic acid, chlorzoxazone, 6-hydroxychlorzoxazone, and phenacetin) in the conditions mentioned above. 
$\mathrm{mV}$

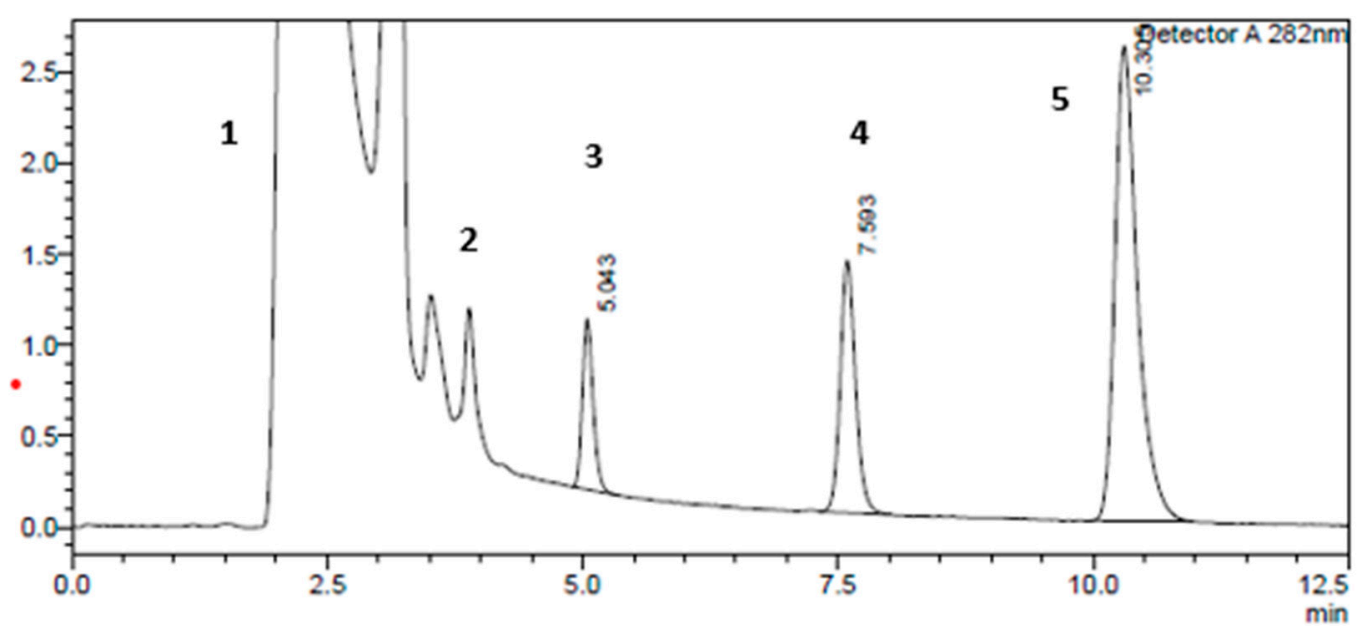

Figure 3. Typical HPLC chromatogram of CYP2E1 components with standard rat microsomal medium (40 min incubation of chlorzoxazone) at $282 \mathrm{~nm}$ wavelength detection with a $200-\mu \mathrm{M}$ chlorzoxazone concentration. The peaks marked are: (1) the nicotinamide adenine dinucleotide phosphate hydrogen (NADPH)-regenerating system, (2) salicylic acid, (3) 6-hydroxychlorzoxazone, (4) phenacetin, and (5) chlorzoxazone, respectively.

\subsubsection{Linearity and Range}

Different solution concentrations of chlorzoxazone $(0,25,50,100,150,200,300$, and $400 \mu \mathrm{M})$ and its metabolite 6-hydroxychlorzoxazone $(0,10,20,40,60,80$, and $100 \mu \mathrm{M})$ were injected into the HPLC instrument for the determination of the standard calibration curves. Calibration curves were assessed by plotting the mean area peak of standards and phenacetin (internal standard) $(50 \mu \mathrm{M})$ versus the concentration of standard (chlorzoxazone and 6-hydroxychlorzoxazone). The outcomes are listed in Table 1 and show good linearities for both chlorzoxazone and 6-hydroxychlorzoxazone, with $r^{2}$ values of 0.9997 and 0.9994 , respectively. The linear regression coefficient was within the acceptable fit $\left(r^{2}>0.99\right)$ according to the International Conference on Harmonization (ICH) guidelines. The \% RSD (relative standard deviation at each different concentration $(\% \mathrm{RSD}<5 \%)$ ) met the ICH guidelines.

Table 1. Analytical performance.

\begin{tabular}{ccc}
\hline Standards & Chlorzoxazone & 6-Hydroxychlorzoxazone \\
\hline Regression equation & $\mathrm{y}=0.0544 \mathrm{x}+0.0626$ & $\mathrm{y}=0.0164 \mathrm{x}-0.0021$ \\
$r^{2}$ & 0.9997 & 0.9994 \\
Linear range & $25-400 \mu \mathrm{M}$ & $10-100 \mu \mathrm{M}$ \\
\hline
\end{tabular}

\subsubsection{Limit of Detection and Limit of Quantitation (LOD and LOQ)}

The results, presented in Table 2, demonstrate that both chlorzoxazone and 6-hydroxychlorzoxazone have low detection and quantitation limit values, consistent with the literature [12].

Table 2. LOD and LOQ for chlorzoxazone and 6-hydroxychlorzoxazone.

\begin{tabular}{ccc}
\hline Standards & Chlorzoxazone & 6-Hydroxychlorzoxazone \\
\hline Limit of Detection (LOD) & $4.972 \mu \mathrm{M}$ & $1.997 \mu \mathrm{M}$ \\
Limit of Quantitation (LOQ) & $15.068 \mu \mathrm{M}$ & $6.052 \mu \mathrm{M}$ \\
\hline
\end{tabular}




\subsubsection{Precision}

\section{Intra-assay Variation of Chlorzoxazone}

Intra-assay variation of chlorzoxazone was determined by measuring three concentration levels $(200,100,25 \mu \mathrm{M}$, or high, medium, low, respectively) three times in a single batch $(n=3)$. Mean activity was calculated from the following calibration curve linear equation: $y=0.0544 x+0.0626\left(r^{2}=0.9997\right)$. The outcomes, summarized in Table 3, demonstrate that the relative standard deviation or \% RSD (percentage of relative standard deviation) was $<5 \%$ for chlorzoxazone. The experiment revealed that there was no large variation in the intra-assay experiment.

Table 3. Intra-assay variation for chlorzoxazone $(n=3)$.

\begin{tabular}{cccc}
\hline Chlorzoxazone Standard & $\begin{array}{c}\text { Mean Activity } \\
(\mu \mathrm{M})\end{array}$ & $\begin{array}{c}\text { Standard } \\
\text { Deviation }\end{array}$ & $\begin{array}{c}\text { Relative Standard } \\
\text { Deviation (\%) }\end{array}$ \\
\hline Low activity standard $(\mathrm{C}=25 \mu \mathrm{M})$ & 36.424 & 1.014 & 2.785 \\
Medium activity standard $(\mathrm{C}=100 \mu \mathrm{M})$ & 106.421 & 0.727 & 0.684 \\
High activity standard $(\mathrm{C}=200 \mu \mathrm{M})$ & 218.814 & 0.599 & 0.274 \\
\hline
\end{tabular}

$\%$ RSD: Percentage of relative standard deviation.

Intra-Assay Variation of 6-hydroxychlorzoxazone Metabolite

Determination of intra-assay variation of the metabolite was assessed by injecting three levels of 6-hydroxy chlorzoxazone concentrations (low, moderate, high) into a HPLC instrument three times in a single batch $(n=3)$. Mean activity was calculated from the following calibration curve linear equation: $y=0.0164 x-0.0021\left(r^{2}=0.9994\right)$. The outcomes, summarized in Table 4 , illustrate that the relative standard deviation or \% RSD (percentage of relative standard deviation) was $<5 \%$ for 6-hydroxychlorzoxazone. The experiment revealed that there is no large variation in the intra-assay experiment.

Table 4. Intra-assay variation of CYP2E1 enzyme metabolite (6-hydroxychlorzoxazone) $(n=3)$.

\begin{tabular}{cccc}
\hline 6-Hydroxy Chlorzoxazone Standard & $\begin{array}{c}\text { Mean Activity } \\
(\mu \mathrm{M})\end{array}$ & $\begin{array}{c}\text { Standard } \\
\text { Deviation }\end{array}$ & $\begin{array}{c}\text { Relative Standard } \\
\text { Deviation (\%) }\end{array}$ \\
\hline Low activity standard $(\mathrm{C}=10 \mu \mathrm{M})$ & 10.114 & 0.038 & 0.385 \\
Moderate activity standard $(\mathrm{C}=40 \mu \mathrm{M})$ & 41.058 & 0.291 & 0.709 \\
High activity standard $(\mathrm{C}=80 \mu \mathrm{M})$ & 81.299 & 0.101 & 0.125 \\
\hline
\end{tabular}

$\%$ RSD: Percentage of relative standard deviation.

Inter-Assay Variation of Chlorzoxazone

Inter-assay variation was determined by measuring chlorzoxazone standards of three concentrations levels $(200,100,25 \mu \mathrm{M}$, or high, medium, low, respectively) for three consecutive days, in separate batches. Mean activity was calculated from the following calibration curve linear equations on days 1, 2, and 3: $\mathrm{y}=0.0544 \mathrm{x}+0.0626\left(\mathrm{r}^{2}=0.9997\right)$ for day $1, \mathrm{y}=0.0522 \mathrm{x}+0.074\left(\mathrm{r}^{2}=0.9994\right)$ for day 2 , and $y=0.024 x-0.0268\left(r^{2}=0.9994\right)$ for day 3 . The results, summarized in Table 5 , illustrate that the relative standard deviation or $\%$ RSD (percentage of relative standard deviation) was $<10 \%$ for chlorzoxazone. The experiment revealed that there is no large variation between aliquots of the same batch sample in the inter-assay experiment. 
Table 5. Inter-assay variation for chlorzoxazone.

\begin{tabular}{|c|c|c|c|c|c|}
\hline Chlorzoxazone Standard $(\mu \mathrm{M}$ & & $\begin{array}{l}\text { Mean Area Peak } \\
(n=3 \text { each level) }\end{array}$ & $\begin{array}{c}\text { Mean }^{a} \\
\text { Activity } \\
(\mu \mathrm{M})\end{array}$ & $\begin{array}{l}\text { Standard } \\
\text { Deviation } \\
\text { (STD) }\end{array}$ & $\begin{array}{l}\text { Relative } \\
\text { Standard } \\
\text { Deviation } \\
\text { (RSD (\%)) }\end{array}$ \\
\hline \multirow{3}{*}{ Low activity standard $(\mathrm{C}=25 \mu \mathrm{M})$} & Day 1 & 1.489 & \multirow{3}{*}{25.245} & \multirow{3}{*}{0.696} & \multirow{3}{*}{2.756} \\
\hline & Day 2 & 1.373 & & & \\
\hline & Day 3 & 0.564 & & & \\
\hline \multirow{3}{*}{ Medium activity standard $(\mathrm{C}=100 \mu \mathrm{M})$} & Day 1 & 5.668 & \multirow{3}{*}{105.088} & \multirow{3}{*}{7.583} & \multirow{3}{*}{7.216} \\
\hline & Day 2 & 6.089 & & & \\
\hline & Day 3 & 2.297 & & & \\
\hline \multirow{3}{*}{ High activity standard $(C=200 \mu \mathrm{M})$} & Day 1 & 11.719 & \multirow{3}{*}{202.275} & \multirow{3}{*}{8.525} & \multirow{3}{*}{4.214} \\
\hline & Day 2 & 10.378 & & & \\
\hline & Day 3 & 4.657 & & & \\
\hline
\end{tabular}

$\%$ RSD: Percentage of relative standard deviation. ${ }^{a}$ Mean concentration $(\mu \mathrm{M})$.

Inter-Assay Variation of 6-Hydroxychlorzoxazone

Assessment of inter-assay variation of 6-hydroxychlorzoxazone was carried out by injecting three concentration levels of 6-hydroxychlorzoxazone (low, moderate, and high) for three consecutive days in separate batches $(n=3)$. Mean activity was calculated from the following calibration curve linear equations on days 1,2 , and 3: $y=0.0164 x-0.0021\left(r^{2}=0.9994\right)$ for day $1, y=0.0248 x$ $-0.0048\left(r^{2}=0.9999\right)$ for day 2 , and $y=0.0277 x-0.0141\left(r^{2}=0.9996\right)$ for day 3 . The outcomes are shown in Table 6, and illustrate that the relative standard deviation or \% RSD was $<10 \%$ for 6-hydroxychlorzoxazone. The experiment revealed that there is no variation between aliquots of the same batch sample in the inter-assay experiment.

Table 6. Inter-assay performance of 6-hydroxychlorzoxazone.

\begin{tabular}{|c|c|c|c|c|c|}
\hline \multicolumn{2}{|c|}{$\begin{array}{l}\text { 6-Hydroxy Chlorzoxazone } \\
\text { Standard }(\mu \mathrm{M})\end{array}$} & \multirow{2}{*}{$\begin{array}{c}\text { Mean Area Peak } \\
(n=3 \text { each level) }\end{array}$} & \multirow[t]{2}{*}{$\begin{array}{l}\text { Mean Activity } \\
(\mu \mathrm{M})\end{array}$} & \multirow[t]{2}{*}{$\begin{array}{c}\text { Standard } \\
\text { Deviation } \\
\text { (STD) }\end{array}$} & \multirow[t]{2}{*}{$\begin{array}{l}\text { Relative } \\
\text { Standard } \\
\text { Deviation } \\
(\text { RSD }(\%))\end{array}$} \\
\hline \multirow{3}{*}{$\begin{array}{l}\text { Low activity } \\
\text { standard } \\
(\mathrm{C}=10 \mu \mathrm{M})\end{array}$} & Day 1 & & & & \\
\hline & Day 2 & 0.242 & \multirow[t]{2}{*}{9.955} & \multirow[t]{2}{*}{0.037} & \multirow[t]{2}{*}{0.367} \\
\hline & Day 3 & 0.263 & & & \\
\hline \multirow{3}{*}{$\begin{array}{c}\text { Medium } \\
\text { activity } \\
\text { standard } \\
(\mathrm{C}=40 \mu \mathrm{M})\end{array}$} & Day 1 & 0.661 & \multirow{3}{*}{41.335} & \multirow{3}{*}{2.219} & \multirow{3}{*}{5.370} \\
\hline & Day 2 & 1.096 & & & \\
\hline & Day 3 & 1.072 & & & \\
\hline \multirow{3}{*}{$\begin{array}{l}\text { High activity } \\
\text { standard } \\
(\mathrm{C}=80 \mu \mathrm{M})\end{array}$} & Day 1 & 1.329 & \multirow{3}{*}{80.498} & \multirow{3}{*}{0.783} & \multirow{3}{*}{0.973} \\
\hline & Day 2 & 2.002 & & & \\
\hline & Day 3 & 2.185 & & & \\
\hline
\end{tabular}

\subsubsection{Stability Test}

\section{Stability Test for Chlorzoxazone}

The stability of chlorzoxazone was investigated for three different concentrations $(25,100$, and $200 \mu \mathrm{M}$ ) stored for $72 \mathrm{~h}$ at room temperature in natural light conditions. Phenacetin (used as an internal standard of $50 \mu \mathrm{M})$ was added to each batch. Each sample was analysed in triplicate $(n=3)$ for each 
batch. The calibration curve of chlorzoxazone was run at $\mathrm{t}=0, \mathrm{t}=24, \mathrm{t}=48$, and $\mathrm{t}=72 \mathrm{~h}$. The stability test results are summarized in the Table 7 , below:

Table 7. Stability test data of chlorzoxazone.

\begin{tabular}{|c|c|c|c|c|}
\hline \multirow{2}{*}{ Analytical Parameters } & \multicolumn{4}{|c|}{ Nominal Level (Actual Concentration of Chlorzoxazone $(\mu \mathrm{M})$ ) } \\
\hline & & 25 & 100 & 200 \\
\hline \multirow{4}{*}{ Calculated concentration $(\mu \mathrm{M})$} & $0 \mathrm{~h}$ & 26.635 & 99.418 & 197.857 \\
\hline & $24 \mathrm{~h}$ & 24.359 & 96.815 & 195.943 \\
\hline & $48 \mathrm{~h}$ & 26.942 & 96.025 & 190.029 \\
\hline & $72 \mathrm{~h}$ & 23.433 & 97.834 & 195.523 \\
\hline \multirow{3}{*}{$\%$ Recovery $^{a}$} & $24 \mathrm{~h}$ & 91.456 & 97.382 & 99.033 \\
\hline & $48 \mathrm{~h}$ & 101.151 & 96.586 & 96.044 \\
\hline & $72 \mathrm{~h}$ & 88.246 & 98.407 & 98.821 \\
\hline \multirow{4}{*}{ Accuracy $^{b}(\%)$} & $0 \mathrm{~h}$ & 93.459 & 100.582 & 101.072 \\
\hline & $24 \mathrm{~h}$ & 102.562 & 103.185 & 102.029 \\
\hline & $48 \mathrm{~h}$ & 92.232 & 103.975 & 104.985 \\
\hline & $72 \mathrm{~h}$ & 106.267 & 102.166 & 102.239 \\
\hline
\end{tabular}

a $\%$ Recovery $=($ concentration of chlorzoxazone at $24 \mathrm{~h}$ )/ Standard concentration of chlorzoxazone $) \times 100$.

${ }^{\mathrm{b}}$ Accuracy $=(($ calculated concentration - actual concentration $) /$ actual concentration $) \times 100$.

The outcomes in Table 7 revealed that there were no variations in the concentrations at $0,24,48$, and $72 \mathrm{~h}$ compared to actual concentrations. Calibration curves were plotted for days 1-4 and all four calibration curves were as follows: day 1: $\mathrm{y}=0.036 \mathrm{x}-0.0744\left(\mathrm{r}^{2}=0.9998\right)$, day 2: $\mathrm{y}=0.0356 \mathrm{x}-0.0103$ $\left(r^{2}=0.9998\right)$, day 3: $y=0.0374 x-0.132\left(r^{2}=0.9994\right)$, and day 4: $y=0.0358 x+0.0298\left(r^{2}=0.9993\right)$, where the $\mathrm{r}^{2}$ met ICH guidelines. Percentage recovery values for chlorzoxazone at concentrations 25 , 100 , and $200 \mu \mathrm{M}$ were found to be within acceptable criteria (80-120\%) according to ICH guidelines. Thus, the results show high and acceptable accuracy (80-120\%) for chlorzoxazone concentrations of 25,100 , and $200 \mu \mathrm{M}$, because the recovery was high (within acceptable range with ICH guidelines) compared with the standard known concentration. The results indicate that chlorzoxazone solution was stable for $72 \mathrm{~h}$ at ambient temperature, in accordance with the study done by Shaikh et al., (2008) [12].

Stability Test for 6-hydroxychlorzoxazone

Stability of 6-hydroxychlorzoxazone was investigated for three different concentrations (10, 40, and $80 \mu \mathrm{M}$ ) stored for $72 \mathrm{~h}$ at room temperature in natural light conditions. Phenacetin (used as an internal standard of $50 \mu \mathrm{M})$ was added to each batch. Each sample was analysed in triplicate $(n=3)$ for each batch. The calibration curve of 6-hydroxychlorzoxazone was run at $t=0, t=24, t=48$, and $\mathrm{t}=72 \mathrm{~h}$. The stability test results are summarized in the Table 8 , below. 
Table 8. Stability test data of 6-hydroxychlorzoxazone.

\begin{tabular}{|c|c|c|c|c|}
\hline \multirow{2}{*}{ Analytical Parameters } & \multicolumn{4}{|c|}{ Nominal Level (Actual Concentration of 6-Hydroxychlorzoxazone $(\mu \mathrm{M})$ ) } \\
\hline & & 10 & 40 & 80 \\
\hline \multirow{4}{*}{ Calculated concentration $(\mu \mathrm{M})$} & $0 \mathrm{~h}$ & 9.537 & 40.431 & 81.391 \\
\hline & $24 \mathrm{~h}$ & 8.848 & 38.719 & 77.154 \\
\hline & $48 \mathrm{~h}$ & 9.039 & 41.731 & 80.298 \\
\hline & $72 \mathrm{~h}$ & 10.580 & 42.359 & 83.591 \\
\hline \multirow{3}{*}{$\%$ Recovery $^{a}$} & $24 \mathrm{~h}$ & 92.774 & 95.767 & 94.794 \\
\hline & $48 \mathrm{~h}$ & 94.782 & 103.217 & 98.657 \\
\hline & $72 \mathrm{~h}$ & 110.099 & 104.772 & 102.702 \\
\hline \multirow{4}{*}{ Accuracy ${ }^{b}(\%)$} & $0 \mathrm{~h}$ & 104.631 & 98.923 & 98.261 \\
\hline & $24 \mathrm{~h}$ & 111.522 & 103.202 & 103.558 \\
\hline & $48 \mathrm{~h}$ & 109.608 & 95.672 & 99.627 \\
\hline & $72 \mathrm{~h}$ & 94.200 & 94.100 & 95.512 \\
\hline
\end{tabular}

a \% recovery $=$ (concentration of 6-hydroxychlorzoxazone at $24 \mathrm{~h}$ )/ standard concentration of 6-hydroxychlorzoxazone) $\times 100 .{ }^{\mathrm{b}}$ Accuracy $=100-(($ calculated concentration - actual concentration $) /$ actual concentration $) \times 100$.

The outcomes in Table 8 revealed that there were no variations in the concentrations at 0,24 , 48 , and $72 \mathrm{~h}$ compared to actual concentrations. Calibration curves were plotted for days 1-4 and all four calibration curves were as follows: day $1: y=0.0255 x-0.0031\left(r^{2}=0.9999\right)$, day 2 : $y=0.0259 x+0.0141\left(r^{2}=0.9995\right)$, day 3: $y=0.0255 x-0.0305\left(r^{2}=0.9991\right)$, and day $4: y=0.0251$ $x-0.0145\left(r^{2}=0.9993\right)$, where the $r^{2}$ met within ICH guidelines. Percentage recovery values for 6-hydroxychlorzoxazone at concentrations 10,40 , and $80 \mu \mathrm{M}$ were found to be within acceptable criteria (80-120\%) according to ICH guidelines. Thus, the results shows high and acceptable accuracy (80-120\%) for 6-hydroxychlorzoxazone concentrations of 10, 40, and $80 \mu \mathrm{M}$, because the recovery was high (within acceptable range with ICH guidelines) compared with the standard known concentration. The results indicate that 6-hydroxychlorzoxazone solution was stable for $72 \mathrm{~h}$ at room temperature, in accordance with the study done by Schelstraete et al. (2018) [13].

\subsection{Effect of Salicylic acid on CYP2E1 Enzyme Activity}

Different concentrations of chlorzoxazone $(200,150,100,50$, and $25 \mu \mathrm{M})$ were incubated in the presence of $0,10,20,40$, and $60 \mu \mathrm{M}$ of salicylic acid using $0.5 \mathrm{mg} / \mathrm{mL}$ of rat liver microsome with $1.0 \mathrm{mM}$ nicotinamide adenine dinucleotide phosphate hydrogen (NADPH), $5.0 \mathrm{mM}$ glucose-6-phosphate (G6P), 1.7 units/mL glucose-6-phosphate dehydrogenase (G6PDH), $1.0 \mathrm{mM}$ ethylenediamine tetraacetic acid (EDTA), and $3.0 \mathrm{mM}$ of magnesium chloride. The reaction was terminated at different sets of time. The incubation time was $40 \mathrm{~min}$. The inhibitory effect of salicylic acid on CYP2E1 enzyme activity is shown in Figures 4 and 5 below. 


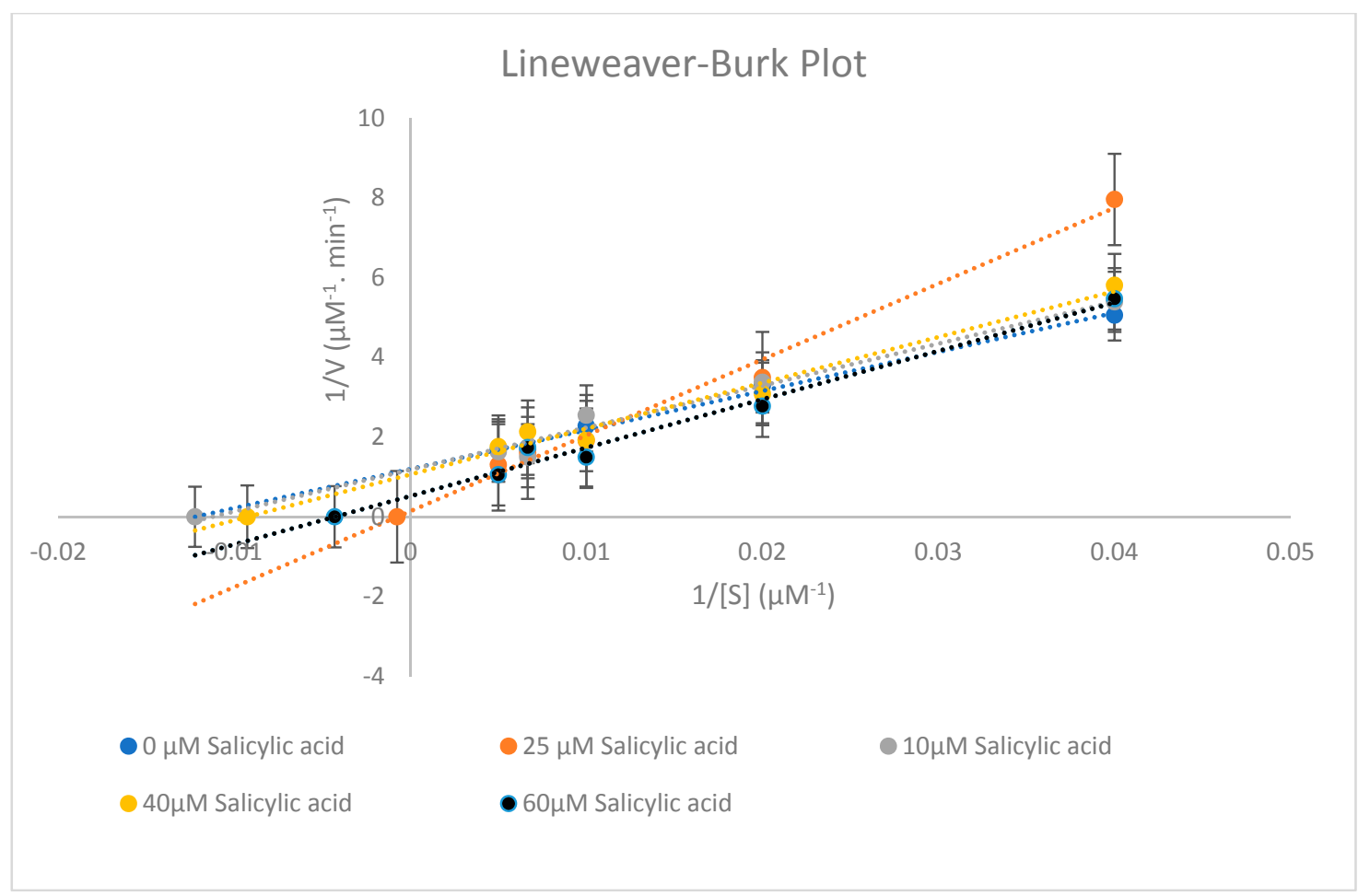

Figure 4. Representative Lineweaver-Burk plot for the inhibition of CYP2E1-catalysed chlorzoxazone 6-hydroxylation (chlorzoxazone $(25-200 \mu \mathrm{M})$ ) with $0,10,25,40$, and $60 \mu \mathrm{M}$ salicylic acid. Each point represents the average of three determinations.

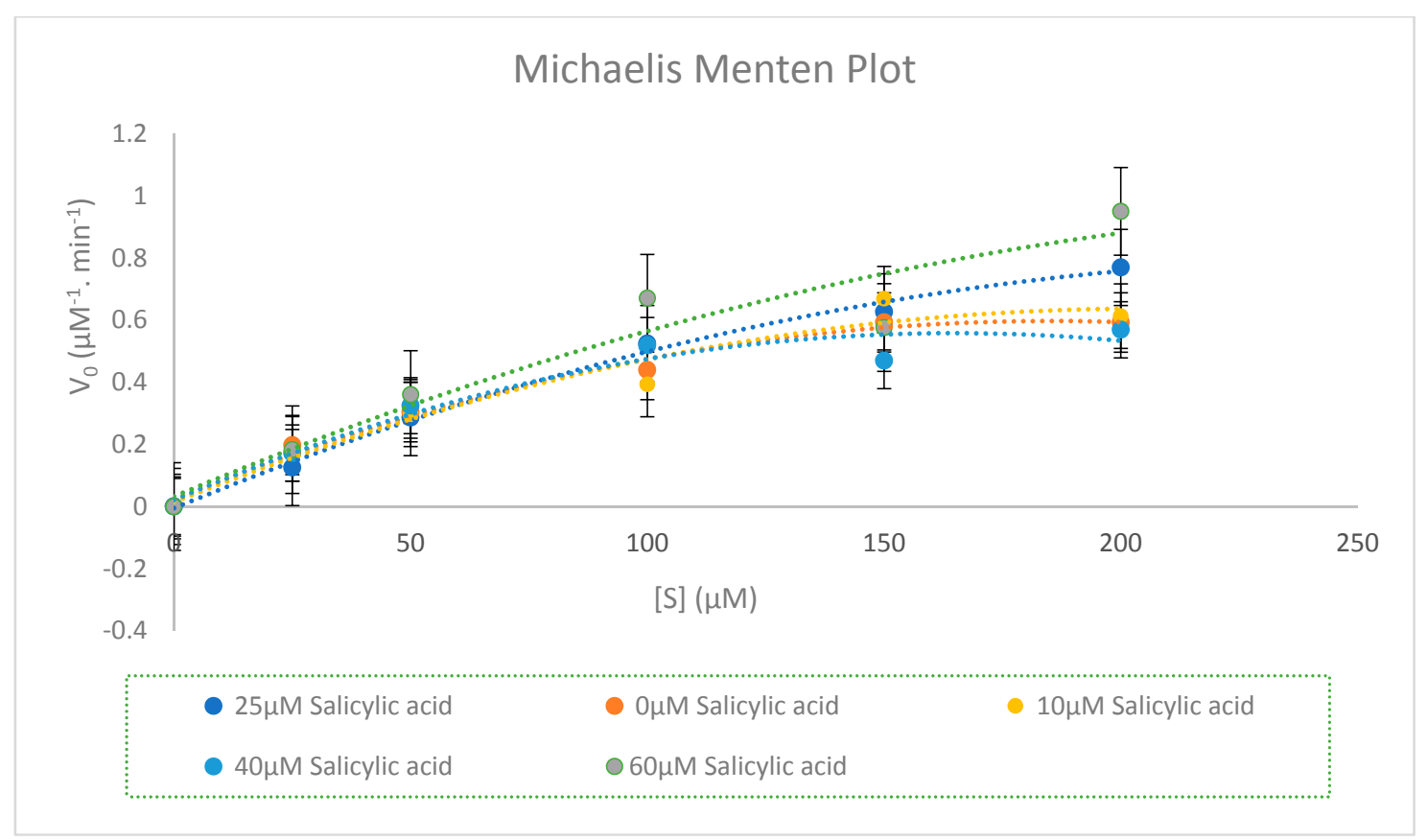

Figure 5. Representative Michaelis-Menten plot for the inhibition of CYP2E1-catalysed chlorzoxazone 6-hydroxylation (chlorzoxazone $(25,50,100,150$, and $200 \mu \mathrm{M})$ ) by 0, 10, 25, 40, and $60 \mu \mathrm{M}$ salicylic acid. The curves were fitted with a polynomial function of order 2. Each point represents the average of three determinations. 
Studying CYP enzyme inhibition is considered as an important route in evaluating drug-drug interactions in the pharmaceutical field and in the drug development process. Several marketed drugs have been withdrawn from the market in the past few decades because CYP enzyme inhibition causes harmful drug-drug interactions [1]. To our knowledge, this systematic study seems to be the first time that the in vitro inhibitory effect of salicylic acid on the CYP2E1 probe substrate metabolism has been investigated.

The CYP2E1 isoform appears to be the most vulnerable when salicylic acid's modulatory effect on each individual isoform is considered. Based on its characteristics, the CYP2E1 isoform has a broad substrate specificity, an ability to metabolise major marketed drugs, and is responsible for the catalysis of many carcinogens and poisons [2].

Only one enzyme exists in the CYP2E isoform and this is known as the CYP2E1 isozyme [14]. CYP2E1 has the ability to metabolize nitrosamines and short-chains such as ethanol, toluene, and paracetamol, and many other anaesthetics actively [15]. Therefore, the CYP2E1 enzyme can be included only in the metabolism of lower molecular weight drugs such as styrene, vinyl chloride, and benzene that are involved in the synthesis of many households cleaning products [16]. The substrates recognized by the CYP2E1 enzyme are chlorzoxazone, p-nitrophenol, coumarin, quinolone, and caffeine [17]. CYP2E1 can activate some of the above carcinogenic substances [14]. Bibi (2008) claimed that the expression of CYP2E1 might differ between genders. Likewise, CYP2E1 activity can be also affected by health conditions such as obesity and fasting, which may provide an apparent clarification for obesity associated with cancer [14].

In vitro evidence has also revealed that garlic and watercress serve as potent inhibitors of the CYP2E1 enzyme in the human body [18]. In addition, nervous system agents, such as isoflurane, ethanol, aflatoxin B1, balothane, and chlorzoxazone, can be preferably metabolised by the CYP2E1 enzyme [1].

Recent studies have suggested that the sensitivity of the CYP2E1 enzyme activity can be decreased by certain drugs and food stuffs for example green and black powder tea, ellagic acid, chrysin, $\mathrm{N}$-acetyl cysteine, and dandelion [18]. Our previous study showed that salicylic acid acts as a non-competitive inhibitor for CYP2C11 enzyme activity [10]. Thus, salicylic acid has a low potency to cause toxicity and drug interaction with other drugs that are substrates for the CYP2C11 enzyme [10]. In this study (Figure 4; Figure 5), it is evident, based on the in vitro inhibition kinetic parameters in rat liver microsomes and Lineweaver plot shapes, that salicylic acid inhibited CYP2E1 activities with a mixed-type inhibition mode (competitive and non-competitive) with inhibition constant, $\mathrm{K}_{\mathrm{i}}=83.56 \pm$ $2.730 \mu \mathrm{M}$ and a 50\% inhibitory concentration ( $\mathrm{IC}_{50}$ ) value exceeding $100 \mu \mathrm{M}\left(\mathrm{IC}_{50}=167.12 \pm 5.460 \mu \mathrm{M}\right)$. In addition, salicylic acid at its concentration of $25 \mu \mathrm{M}$ can considered as a saturated concentration, since its Michaelis constant $K_{m}$ value represents the highest value compared to other salicylic acid concentrations. According to Table $9, K_{m}$ and the maximum rate of the reaction $\left(V_{\max }\right)$ hanged between each concentration of salicylic acid, and thus salicylic acid acts as a mixed inhibition for CYP2E1 enzyme activity. Thus, in this study it is considered that the in vitro inhibitory effect of salicylic acid on CYP2E1 enzyme activity will be beneficial for a future in vivo study for healthcare screening of the effective use of salicylic acid in clinics and the safe administration of salicylic acid with other drugs, consistent with in vivo drug-drug interactions pharmacokinetic parameters. Some further investigational in vitro and in vivo studies in human CYP450s are needed due to the varied CYP2E isoform expression in species. 
Table 9. Calculated parameters of enzyme metabolism for the in vitro CYP2E1 inhibition study.

\begin{tabular}{cccccc}
\hline $\begin{array}{c}\text { Parameters of Enzyme } \\
\text { Metabolism }\end{array}$ & $\begin{array}{c}\mathbf{0} \boldsymbol{\mu M} \text { Salicylic } \\
\text { Acid }\end{array}$ & $\begin{array}{c}\mathbf{1 0} \boldsymbol{\mu M} \\
\text { Salicylic Acid }\end{array}$ & $\begin{array}{c}\mathbf{2 5} \boldsymbol{\mu M} \text { Salicylic } \\
\text { Acid }\end{array}$ & $\begin{array}{c}\mathbf{4 0} \boldsymbol{\mu M} \\
\text { Salicylic Acid }\end{array}$ & $\begin{array}{c}\mathbf{6 0} \boldsymbol{\mu M} \\
\text { Salicylic Acid }\end{array}$ \\
\hline $\mathrm{K}_{\mathrm{m}}(\mu \mathrm{M})$ & $88.731 \pm 6.003$ & $81.732 \pm 6.517$ & $1322.751 \pm 0.403$ & $107.991 \pm 4.932$ & $232.306 \pm 0.762$ \\
\hline $\begin{array}{c}\mathrm{V}_{\max } \\
\left(\mu \mathrm{M}^{-1} \cdot \mathrm{min}^{-1}\right)\end{array}$ & $0.842 \pm 0.186$ & $0.834 \pm 0.220$ & $6.954 \pm 0.033$ & $0.939 \pm 0.154$ & $1.915 \pm 0.972$ \\
\hline $\begin{array}{c}\mathrm{Cl}_{\mathrm{int}} \\
\left(\mu \mathrm{M}^{-2} \cdot \mathrm{min}^{-1}\right)\end{array}$ & $0.0094 \pm 0.202$ & $0.0102 \pm 0.186$ & $0.0053 \pm 0.359$ & $0.0087 \pm 0.218$ & $0.0082 \pm 0.002$ \\
\hline $\mathrm{K}_{\mathrm{m}}:$ Michaelis constant. $\mathrm{V}_{\text {max }}$ : Maximum rate of the reaction. $\mathrm{Cl}_{\text {int }}:$ Hepatic intrinsic clearance.
\end{tabular}

\section{Materials and Methods}

\subsection{Chemicals and Reagents}

6-Hydroxychlorzoxazone was purchased from Carbosynth limited (Compton, UK). Glucose-6-phosphate (G-6-P), glucose-6-phosphate dehydrogenase (G-6-PDH), ethylenediamine tetraacetic acid (EDTA), nicotinamide adenine dinucleotide phosphate $\left(\mathrm{NADP}^{+}\right)$, magnesium chloride $\left(\mathrm{MgCL}_{2}\right)$, and chlorzoxazone were purchased from Merck (Old Brickyard, Gillingham, UK). Methanol, acetonitrile, and water were of HPLC grade; salicylic acid, potassium phosphate monobasic, potassium phosphate dibasic, phenacetin with purity greater than $98 \%$, and phosphoric acid $(85 \% w / w)$ were purchased from Merck (Old Brickyard, Gillingham, UK).

\subsection{Rat Liver Microsomes}

Microsomes from liver, pooled from male rat (Sprague-Dawley) in this study were purchased from Merck (Old Brickyard, Gillingham, UK) and stored at $-80{ }^{\circ} \mathrm{C}$. The manufacturer had previously characterized the microsomes for CYP2E1 activity, CYP450 content, and protein concentrations.

\subsection{Instruments}

A Shimadzu LC-2010A HT high performance liquid chromatography system equipped with a low-pressure pump quaternary gradient (series 200 LC pump), a series 200 Peltier LC column oven for chromatographing the analysed solutions, a series 200 autosampler (Shimadzu, Tokyo, Japan), a degasser, and a model series $200 \mathrm{UV}$ detector were used. The data were processed using the Shimadzu HPLC 2 Data Lab Solutions (Kingston University, UK) software processing system. A 5- $\mu$ m $C_{18}$ SUPLCO column $(25 \mathrm{~cm} \times 4.6 \mathrm{~mm})$ was employed from Merck (Old Brickyard, Gillingham, UK) to separate target analytes using a low-pressure isocratic elution system. A UV-VIS Spectrometry instrument with a 1-cm-length quartz cuvette was purchased from VWR International Ltd. (Magna Park, Lutterworth, Leicestershire, LE17 4XN, UK) and UV spectra were processed using a Bio 100 Cary software from Agilent Technologies LDA (Cheadle Royal Business Park, Stockport, Cheshire, SK8 3GR, UK). A 570 pH meter, purchased from JENWAY Limited (Beacon Road, Stone, Staffordshire, ST15 0SA, UK) was used.

\subsection{CYP450 Assay}

\subsubsection{CYP2E1 Substrate and its Metabolite}

Validations were conducted using HPLC system LC-2010A HT Module (Shimadzu, Tokyo, Japan). Chromatographic experiments were evaluated in a low-pressure isocratic system. The separations of the four target components (salicylic acid as a tested inhibitor, phenacetin as an internal standard, chlorzoxazone as CYP2E1 substrate, and 6-hydroxychlorzoxazone as CYP2E1 metabolite) were injected into a SUPELCO C18 column $(25 \mathrm{~cm} \times 4.6 \mathrm{~mm}, 5 \mu \mathrm{m}$ particle size). The mobile phase for the chromatographic separation of the four compounds was made up as follows: (A): $60 \% \mathrm{H}_{2} \mathrm{O}$, (B): $15 \%$ of methanol, and (C): $25 \%$ of acetonitrile. The flow rate was set to $0.7 \mathrm{~mL} / \mathrm{min}$, and the oven temperature 
was set at $25^{\circ} \mathrm{C}$. Wavelength detection was set to $282 \mathrm{~nm}$. An injection volume of $10 \mu \mathrm{L}$ was used. The mobile phase consisted of methanol: water: acetonitrile (15:60:25 \% v/v). This provided a good separation and resolution of CYP2E1 components.

\subsubsection{Inhibition of CYP2E1 Enzymatic Activity Assay}

CYP2E1 activity was assessed using chlorzoxazone (substrate) via the formation of 6-hydroxychlorzoxazone (the metabolite for the CYP2E1 enzyme). Oxidative metabolism of chlorzoxazone was evaluated using a NADPH-regenerating system consisting of: $1.0 \mathrm{mM}$ nicotinamide adenine dinucleotide phosphate hydrogen (NADPH), $5 \mathrm{mM}$ glucose-6-phosphate (G6P), $1.7 \mathrm{units} / \mathrm{mL}$ glucose-6-phosphate dehydrogenase (G6PDH), $1.0 \mathrm{mM}$ ethylenediamine tetraacetic acid (EDTA), and $3.0 \mathrm{mM}$ magnesium chloride. A $500-\mu \mathrm{L}$ incubation volume containing NADPH-regenerating system and a final concentration of $0.067 \mathrm{M}$ potassium phosphate buffer at $\mathrm{pH}=7.4$ was incubated in triplicate. The incubation mixture consisted of $0.5 \mathrm{mg} / \mathrm{mL}$ of pooled liver microsomes with a serial range of chlorzoxazone concentrations $(25,50,100,150$, and $200 \mu \mathrm{M}$, dissolved in mobile phase) and a serial range of salicylic acid concentrations $(0,10,25,40$, and $60 \mu \mathrm{M}$, dissolved in mobile phase). Pre-incubation of all components was done for $10 \mathrm{~min}$ in a water bath at $\mathrm{T}=37^{\circ} \mathrm{C}$ before the addition of nicotinamide adenine dinucleotide phosphate $\left(\mathrm{NADP}^{+}\right)$into the mixture [19]. The final concentration of organic solvent did not exceed the $1 \% v / v$. Tubes were incubated for $40 \mathrm{~min}$ in an Eppendorf thermomixer (Eppendorf UK Limited, Stevenage) at $150 \mathrm{rpm}\left(37^{\circ} \mathrm{C}\right)$. Termination of the reaction was carried out by adding ice-cold acetonitrile containing $50 \mu \mathrm{M}$ of phenacetin as an internal standard at each time interval $(10,15,20,25,30,35$, and $40 \mathrm{~min})$. Tubes were centrifuged in a microcentrifuge $(13,000 \times g)$ for $12 \mathrm{~min}$ to precipitate protein. Then the supernatant was collected and dissolved in a mobile phase $\left(60 \% \mathrm{H}_{2} \mathrm{O}, 15 \%\right.$ methanol, and $25 \%$ acetonitrile) made up to $1000 \mu \mathrm{L}$ volume. A $10-\mu \mathrm{L}$ injection volume of the dissolved supernatant was used for HPLC analysis.

\subsection{Selection of Analytical Wavelength:}

\section{CYP2E1 Assay}

UV-VIS spectrometry using methanol as a blank was evaluated for phenacetin (50 $\mu \mathrm{M})$, salicylic acid $(100 \mu \mathrm{M})$, chlorzoxazone $(200 \mu \mathrm{M})$, and 6-hydroxychlorzoxazone $(50 \mu \mathrm{M})$ standard solutions in the UV region of 200-350 $\mathrm{nm}$.

\subsection{Preparation of Mobile Phase:}

\section{CYP2E1 Assay}

Various mobile phases for CYP2E1 assay were tested. The most suitable mobile phase was: HPLC grade methanol (low UV cut-off of $205 \mathrm{~nm}$ ) as mobile phase (A), $\mathrm{H}_{2} \mathrm{O}$ as mobile phase (B), and HPLC grade acetonitrile as mobile phase (C) (A: 15\%, B: 60\%, C:25\%).

\subsection{Preparation of Standard and Sample Solutions}

\section{Analytes and Metabolite Standard Solution Preparation}

Salicylic acid (SA) $(1.38 \mathrm{mg})(\mathrm{C}=200 \mu \mathrm{M})$ was measured accurately and dissolved in a 50-mL volumetric flask by a mobile phase $\left(60 \% \mathrm{H}_{2} \mathrm{O}, 25 \%\right.$ acetonitrile, and $15 \%$ methanol). Serial dilutions were performed, yielding final concentrations of 40,25 , and $10 \mu \mathrm{M}$. Chlorzoxazone $(3.39 \mathrm{mg})(\mathrm{C}=400 \mu \mathrm{M})$ was weighed accurately and dissolved in a mobile phase $\left(60 \% \mathrm{H}_{2} \mathrm{O}, 25 \%\right.$ acetonitrile, and $15 \%$ methanol). A serial dilution of chlorzoxazone stock solution was made, yielding to final concentrations of 300, 200, 150, 100, 50, and $25 \mu \mathrm{M}$. Phenacetin powder $(0.9 \mathrm{mg})$ was weighed and dissolved in pure HPLC-grade acetonitrile. The metabolite for the CYP2E1 enzyme (6-hydroxychlorzoxazone) was 
prepared as a stock solution of $C=100 \mu \mathrm{M}$, followed by a range of serial dilutions $(80,60,40,20$, and $10 \mu \mathrm{M})$.

\subsection{Data Analysis:}

Standard/calibration curves consisted of different concentration ranges of chlorzoxazone, 6-hydroxychlorzoxane, and a fixed concentration of phenacetin $(50 \mu \mathrm{M})$ as an internal standard. Validation parameters (Range, LOD, LOQ, \% error, recovery, and accuracy) were calculated using Microsoft Excel 2010 software. All results are presented as mean \pm S.D.

Formation of the 6-hydroxychlorzoxazone metabolite of the tested CYP2E1 substrate (chlorzoxazone) was measured for CYP inhibition analysis. Microsoft Excel 2010 software was used for determination of area peak ratios of both metabolite and internal standard. Pharmacokinetic parameters $\left(V_{\mathrm{m}}, K_{\mathrm{m}}, C l_{\text {int }}\right.$ (hepatic intrinsic clearance), $K_{\mathrm{i}}$ ) were determined by nonlinear regression analysis from secondary Lineweaver-Burk and Michaelis-Menten plots of the enzyme activity-metabolite concentration data. The type of CYP2E1 inhibition was assumed to be mixed inhibition based on the shape of Lineweaver-Burk plots, the standard error, the Akaike information criterion (AIC), and Schwarz criterion (SC) values, which were fitted by a simple non-linear regression model. A non-linear regression model was chosen as a better fit because of its low AIC value. The Akaike weights $(\triangle \mathrm{AIC})$ are the relative difference between the best model and each other model in the set. The $\triangle \mathrm{AIC}$ provided substantial evidence for the model $(\triangle \mathrm{AIC}<2)$. The $50 \%$ inhibitory concentration $\left(\mathrm{IC}_{50}\right)$ value was calculated by using the following mixed inhibition equation:

$$
\mathrm{V}=\left[\mathrm{V}_{0} /\left(1+\left(\mathrm{I} / \mathrm{IC}_{50}\right)^{\mathrm{S}}\right)\right]
$$

where $\mathrm{V}$ is the observed velocity, $\mathrm{V}_{0}$ is uninhibited velocity, $\mathrm{S}$ is slope factor, and $\mathrm{I}$ is the inhibitor concentration.

\section{Conclusions}

In conclusion, all the analytical parameters (accuracy, precision, \% error, \% recovery, LOD, LOQ, linear regression) for chlorzoxazone and 6-hydroxychlorzoxazone were in line with ICH guidelines. The in vitro data provided allow us to understand the drug interactions with salicylic acid. Nevertheless, our findings indicated that salicylic acid potentially acts as a mixed inhibitor (competitive and non-competitive inhibitor) for CYP2E1 enzyme activity in rat liver microsomes. This finding provides useful data for the efficacy and the safe use of salicylic acid in clinical practice. However, the extent to which our obtained data can be related to human CYP isoforms is unknown. The majority of clinically important drugs such as S-warfarin, steroids, and retinoic acid are metabolised by both rat CYP2C11 and human CYP2C9 that display a high identity of amino acid sequences. Thus, it is primarily important to investigate whether human CYP isoforms are induced by salicylic acid, and further verification of the obtained in vitro data should be done with in vivo experiments.

Author Contributions: All authors designed, conceived, and performed the experiments. All authors contributed to formal data analysis, interpretations, and writing of the original draft. All authors have read and agreed to the published version of the manuscript.

Funding: This research did not receive any specific grant from funding agencies in the public, commercial, or not-for-profit sectors.

Acknowledgments: We thank Siamak Soltani-Khankahdani and Rizwan Merali from Kingston University for their technical assistance.

Conflicts of Interest: The authors declare no conflict of financial interest or any financial involvement with any company. 


\section{Appendix A. Robustness Testing:}

\section{A.1. Changing the Composition of Mobile Phase:}

HPLC chromatogram obtained in (Figure 3) was performed by changing the $\%$ of mobile phase using isocratic elution of $\left(50 \% \mathrm{H}_{2} \mathrm{O}+25 \%\right.$ of Acetonitrile $+25 \%$ of Methanol). Table A1 indicates that CXZ and Phenacetin peaks had a better resolution (Difference $=3.0544 \mathrm{~min})$ when using $(60 \%$ $\mathrm{H}_{2} \mathrm{O}+25 \%$ of Acetonitrile $+15 \%$ of Methanol) compared to $\left(50 \% \mathrm{H}_{2} \mathrm{O}+25 \%\right.$ of Acetonitrile $+25 \%$ of Methanol) $($ Difference $=1.50367 \mathrm{~min})$. Additionally, selectivity, area peak remains unaffected between both cases.

Table A1. Variation in retention time, and resolution between compounds when changing the composition of mobile phase.

\begin{tabular}{|c|c|c|c|c|}
\hline $\begin{array}{l}\text { Mobile Phase } \\
\text { composition }\end{array}$ & $\begin{array}{l}\text { Compounds } \\
\text { present in the } \\
\text { sample }\end{array}$ & $\begin{array}{l}\text { Average Retention } \\
\text { time } \\
(\mathrm{min})\end{array}$ & $\begin{array}{l}\text { Average Area peak } \\
\quad(\text { Mean } \pm \text { Std })\end{array}$ & Resolution \\
\hline \multirow{4}{*}{$\begin{array}{l}\text { Isocratic elution } \\
\text { mode } \\
\left(60 \% \mathrm{H}_{2} \mathrm{O}+25 \%\right. \\
\text { Acetonitrile }+15 \% \\
\text { Methanol })\end{array}$} & $\begin{array}{l}\text { Salicylic acid } \\
\quad(100 \mu \mathrm{M})\end{array}$ & 3.425 & $153201.667 \pm 0.1842$ & \multirow{4}{*}{$\begin{array}{l}\text { Better resolution } \\
\text { obtained between } \\
\text { four components. }\end{array}$} \\
\hline & Phenacetin $(50 \mu \mathrm{M})$ & 7.7476 & $12049.667 \pm 1.1991$ & \\
\hline & $\begin{array}{l}\text { Chlorzoxazone } \\
\qquad(200 \mu \mathrm{M})\end{array}$ & 10.802 & $252134 \pm 0.0332$ & \\
\hline & $\begin{array}{l}\text { 6-hydroxy } \\
\text { chlorzoxazone } \\
(50 \mu \mathrm{M})\end{array}$ & 5.2433 & $32907.333 \pm 0.5274$ & \\
\hline \multirow{4}{*}{$\begin{array}{c}\text { Isocratic elution } \\
\text { mode } \\
\left(50 \% \mathrm{H}_{2} \mathrm{O}+25 \%\right. \\
\text { Acetonitrile }+25 \% \\
\text { Methanol })\end{array}$} & $\begin{array}{l}\text { Salicylic acid } \\
\qquad(100 \mu \mathrm{M})\end{array}$ & 2.8243 & $153450.667 \pm 0.4506$ & \multirow{4}{*}{$\begin{array}{l}\text { Good resolution } \\
\text { obtained between } \\
\text { four components }\end{array}$} \\
\hline & Phenacetin $(50 \mu \mathrm{M})$ & 6.06866 & $12689 \pm 0.558$ & \\
\hline & $\begin{array}{l}\text { Chlorzoxazone } \\
\qquad(200 \mu \mathrm{M})\end{array}$ & 7.57233 & $255454.667 \pm 0.071$ & \\
\hline & $\begin{array}{l}\text { 6-hydroxy } \\
\text { chlorzoxazone } \\
(50 \mu \mathrm{M})\end{array}$ & 4.57033 & $31590.3333 \pm 1.837$ & \\
\hline
\end{tabular}

When the composition of Acetonitrile increased by 10\%, CXZ and Phenacetin peaks were poorly resolved (Difference $=0.8203 \mathrm{~min})$ compared to normal condition $\left(60 \% \mathrm{H}_{2} \mathrm{O}+25 \%\right.$ of Acetonitrile + $15 \%$ of Methanol) (Difference $=3.0544 \mathrm{~min}$ ). Thus, selectivity, area peak, remains unaffected between both cases as shown in Table A2. 
Table A2. Variation in retention time, and resolution between compounds when changing the composition of mobile phase.

\begin{tabular}{|c|c|c|c|c|}
\hline $\begin{array}{l}\text { Mobile Phase } \\
\text { composition }\end{array}$ & $\begin{array}{l}\text { Compounds } \\
\text { present in the } \\
\text { sample }\end{array}$ & $\begin{array}{c}\text { Average Retention } \\
\text { time } \\
(\mathrm{min})\end{array}$ & $\begin{array}{l}\text { Average Area peak } \\
\quad(\text { Mean } \pm \text { Std })\end{array}$ & Resolution \\
\hline \multirow{4}{*}{$\begin{array}{c}\text { Isocratic elution } \\
\text { mode } \\
\left(60 \% \mathrm{H}_{2} \mathrm{O}+25 \%\right. \\
\text { Acetonitrile }+15 \% \\
\text { Methanol })\end{array}$} & $\begin{array}{l}\text { Salicylic acid } \\
\quad(100 \mu \mathrm{M})\end{array}$ & 3.425 & $153201.667 \pm 0.1842$ & \multirow{4}{*}{$\begin{array}{l}\text { Good resolution } \\
\text { obtained between } \\
\text { four components. }\end{array}$} \\
\hline & Phenacetin $(50 \mu \mathrm{M})$ & 7.7476 & $12049.667 \pm 1.1991$ & \\
\hline & $\begin{array}{c}\text { Chlorzoxazone } \\
(200 \mu \mathrm{M})\end{array}$ & 10.802 & $252134 \pm 0.0332$ & \\
\hline & $\begin{array}{l}\text { 6-hydroxy } \\
\text { chlorzoxazone } \\
(50 \mu \mathrm{M})\end{array}$ & 5.2433 & $32907.333 \pm 0.5274$ & \\
\hline \multirow{4}{*}{$\begin{array}{c}\text { Isocratic elution } \\
\text { mode } \\
\left(50 \% \mathrm{H}_{2} \mathrm{O}+35 \%\right. \\
\text { Acetonitrile }+15 \% \\
\text { Methanol })\end{array}$} & $\begin{array}{l}\text { Salicylic acid } \\
\quad(100 \mu \mathrm{M})\end{array}$ & 2.763 & $151841 \pm 0.0609$ & \multirow{4}{*}{$\begin{array}{c}\text { Bad resolution } \\
\text { obtained between } \\
\text { Chlorzoxazone and } \\
\text { Phenacetin peaks. }\end{array}$} \\
\hline & Phenacetin $(50 \mu \mathrm{M})$ & 5.54 & $12819.667 \pm 1.3304$ & \\
\hline & $\begin{array}{c}\text { Chlorzoxazone } \\
(200 \mu \mathrm{M})\end{array}$ & 6.3603 & $2553360 \pm 0.1121$ & \\
\hline & $\begin{array}{c}\text { 6-hydroxy } \\
\text { chlorzoxazone } \\
(50 \mu \mathrm{M})\end{array}$ & 4.282 & $28947.3333 \pm 0.6372$ & \\
\hline
\end{tabular}

\section{A.2. Changing the Flow Rate:}

Robustness studies were performed by changing the flow rate, and evaluate the variation in retention time and area peak of each component for CYP2E1 assay. Tables A3 and A4 show the effect of flow rate on both retention time and area peak of each compound.

Table A3. Variation in retention time, and area peak between compounds when changing the flow rate.

\begin{tabular}{|c|c|c|c|c|}
\hline $\begin{array}{l}\text { Mobile Phase } \\
\text { composition }\end{array}$ & $\begin{array}{l}\text { Compounds } \\
\text { present in the } \\
\text { sample }\end{array}$ & $\begin{array}{c}\text { Average Retention } \\
\text { time } \\
(\mathrm{min})\end{array}$ & $\begin{array}{l}\text { Average Area peak } \\
\quad(\text { Mean } \pm \text { Std) }\end{array}$ & Resolution \\
\hline \multirow{4}{*}{$\begin{array}{c}\text { Isocratic elution } \\
\text { mode } \\
\left(60 \% \mathrm{H}_{2} \mathrm{O}+25 \%\right. \\
\text { Acetonitrile }+15 \% \\
\text { Methanol }) \\
\text { Flow rate }=0.7 \\
\mathrm{~mL} / \mathrm{min}\end{array}$} & $\begin{array}{c}\text { Salicylic acid } \\
(100 \mu \mathrm{M})\end{array}$ & 3.425 & $153201.667 \pm 0.1842$ & \multirow{4}{*}{$\begin{array}{l}\text { Better resolution } \\
\text { obtained between } \\
\text { four components. } \\
\text { (Difference } \\
\text { between } \\
\text { Phenacetin and } \\
\text { Chlorzoxazone } \\
\text { peaks = 3.0544 min) }\end{array}$} \\
\hline & Phenacetin $(50 \mu \mathrm{M})$ & 7.7476 & $12049.667 \pm 1.1991$ & \\
\hline & $\begin{array}{l}\text { Chlorzoxazone } \\
\qquad(200 \mu \mathrm{M})\end{array}$ & 10.802 & $252134 \pm 0.0332$ & \\
\hline & $\begin{array}{l}\text { 6-hydroxy } \\
\text { chlorzoxazone } \\
(50 \mu \mathrm{M})\end{array}$ & 5.2433 & $32907.333 \pm 0.5274$ & \\
\hline \multirow{4}{*}{$\begin{array}{c}\text { Isocratic elution } \\
\text { mode } \\
\left(60 \% \mathrm{H}_{2} \mathrm{O}+25 \%\right. \\
\text { Acetonitrile }+15 \% \\
\text { Methanol }) \\
\text { Flow rate }=0.9 \\
\text { mL/min }\end{array}$} & $\begin{array}{l}\text { Salicylic acid } \\
\quad(100 \mu \mathrm{M})\end{array}$ & 2.67966 & $118659.667 \pm 0.1625$ & \multirow{4}{*}{$\begin{array}{l}\text { Good resolution } \\
\text { obtained between } \\
\text { four components. } \\
\text { (Difference } \\
\text { between } \\
\text { Phenacetin and } \\
\text { Chlorzoxazone } \\
\text { peaks = 2.2923 min) }\end{array}$} \\
\hline & Phenacetin $(50 \mu \mathrm{M})$ & 5.9703 & $9467.333 \pm 0.7220$ & \\
\hline & $\begin{array}{l}\text { Chlorzoxazone } \\
(200 \mu \mathrm{M})\end{array}$ & 8.2626 & $196024.667 \pm 0.1079$ & \\
\hline & $\begin{array}{l}\text { 6-hydroxy } \\
\text { chlorzoxazone } \\
(50 \mu \mathrm{M})\end{array}$ & 4.0373 & $25901.333 \pm 0.1912$ & \\
\hline
\end{tabular}


According to Table A3, better resolution obtained at flow rate $=0.7 \mathrm{~mL} / \mathrm{min}$ compared to flow rate $=0.9 \mathrm{~mL} / \mathrm{min}$. In addition to that, area peak remains unaffected by small for all components of CYP2E1 assay.

When the flow rate decreased to $0.5 \mathrm{~mL} / \mathrm{min}$, Salicylic acid and 6-hydroxychlorzoxazone peaks were poorly resolved (Difference $=1.2323 \mathrm{~min}$ ) compared to a flow rate $=0.7 \mathrm{~mL} / \mathrm{min}$ (Difference $=1.8183$ min). Additionally, area peak of each CYP2E1 compounds remains unaffected by little as shown in Table A4.

Table A4. Variation in retention time, and area peak between compounds when changing the flow rate.

\begin{tabular}{|c|c|c|c|c|}
\hline $\begin{array}{l}\text { Mobile Phase } \\
\text { composition }\end{array}$ & $\begin{array}{l}\text { Compounds } \\
\text { present in the } \\
\text { sample }\end{array}$ & $\begin{array}{c}\text { Average Retention } \\
\text { time } \\
\text { (min) }\end{array}$ & $\begin{array}{l}\text { Average Area peak } \\
\quad(\text { Mean } \pm \text { Std })\end{array}$ & Resolution \\
\hline \multirow{4}{*}{$\begin{array}{l}\text { Isocratic elution } \\
\text { mode } \\
\left(60 \% \mathrm{H}_{2} \mathrm{O}+25 \%\right. \\
\text { Acetonitrile }+15 \% \\
\text { Methanol }) \\
\text { Flow rate }=0.7 \\
\mathrm{~mL} / \mathrm{min}\end{array}$} & $\begin{array}{l}\text { Salicylic acid } \\
\quad(100 \mu \mathrm{M})\end{array}$ & 3.425 & $153201.667 \pm 0.1842$ & \multirow{4}{*}{$\begin{array}{l}\text { Better resolution obtained } \\
\text { between four components. } \\
\text { (Difference between Salicylic } \\
\text { acid and } \\
\text { 6-hydroxychlorzoxazone } \\
\text { peaks = } 1.8183 \mathrm{~min} \text { ) }\end{array}$} \\
\hline & Phenacetin $(50 \mu \mathrm{M})$ & 7.7476 & $12049.667 \pm 1.1991$ & \\
\hline & $\begin{array}{l}\text { Chlorzoxazone } \\
\qquad(200 \mu \mathrm{M})\end{array}$ & 10.802 & $252134 \pm 0.0332$ & \\
\hline & $\begin{array}{c}\text { 6-hydroxy } \\
\text { chlorzoxazone }(50 \mu \mathrm{M})\end{array}$ & 5.2433 & $32907.333 \pm 0.5274$ & \\
\hline \multirow{4}{*}{$\begin{array}{c}\text { Isocratic elution } \\
\text { mode } \\
\left(60 \% \mathrm{H}_{2} \mathrm{O}+25 \%\right. \\
\text { Acetonitrile }+15 \% \\
\text { Methanol }) \\
\text { Flow rate }=0.5 \\
\mathrm{~mL} / \mathrm{min}\end{array}$} & $\begin{array}{l}\text { Salicylic acid } \\
\qquad(100 \mu \mathrm{M})\end{array}$ & 3.581333 & $213906.667 \pm 0.1896$ & \multirow{4}{*}{$\begin{array}{l}\text { Good resolution obtained } \\
\text { between four components. } \\
\text { (Difference between Salicylic } \\
\text { acid and } \\
\text { 6-hydroxychlorzoxazone } \\
\text { peaks }=1.2323 \mathrm{~min} \text { ) }\end{array}$} \\
\hline & Phenacetin $(50 \mu \mathrm{M})$ & 10.6126 & $17133.333 \pm 1.500$ & \\
\hline & $\begin{array}{l}\text { Chlorzoxazone } \\
\qquad(200 \mu \mathrm{M})\end{array}$ & 7.6806 & $354948.33 \pm 0.358$ & \\
\hline & $\begin{array}{c}\text { 6-hydroxy } \\
\text { chlorzoxazone } \\
(50 \mu \mathrm{M})\end{array}$ & 4.81366 & $25470.333 \pm 2.229$ & \\
\hline
\end{tabular}

\section{A.3. Changing the Column Temperature:}

Robustness studies were performed by changing the column Temperature, and evaluate the variation in retention time and area peak of each component for CYP2E1 assay. Tables A5 and A6 shows the effect of temperature on both retention time and area peak of each compound. 
Table A5. Variation in area peak, retention time of each CYP2E1 compounds when changing the column temperature.

\begin{tabular}{|c|c|c|c|c|}
\hline $\begin{array}{l}\text { Mobile Phase } \\
\text { composition }\end{array}$ & $\begin{array}{l}\text { Compounds } \\
\text { present in the } \\
\text { sample }\end{array}$ & $\begin{array}{c}\text { Average Retention } \\
\text { time } \\
\text { (min) }\end{array}$ & $\begin{array}{l}\text { Average Area peak } \\
\quad(\text { Mean } \pm \text { Std) }\end{array}$ & Resolution \\
\hline \multirow{4}{*}{$\begin{array}{c}\text { Isocratic elution } \\
\text { mode } \\
\left(60 \% \mathrm{H}_{2} \mathrm{O}+25 \%\right. \\
\text { Acetonitrile }+15 \% \\
\text { Methanol }) \\
\mathrm{T}=25^{\circ} \mathrm{C}\end{array}$} & $\begin{array}{l}\text { Salicylic acid } \\
\quad(100 \mu \mathrm{M})\end{array}$ & 3.425 & $153201.667 \pm 0.1842$ & \multirow{4}{*}{$\begin{array}{l}\text { Better resolution } \\
\text { obtained between } \\
\text { four components. } \\
\text { (Difference } \\
\text { between } \\
\text { Phenacetin and } \\
\text { chlorzoxazone } \\
\text { peaks = 3.0544 min) }\end{array}$} \\
\hline & Phenacetin $(50 \mu \mathrm{M})$ & 7.7476 & $12049.667 \pm 1.1991$ & \\
\hline & $\begin{array}{l}\text { Chlorzoxazone } \\
\qquad(200 \mu \mathrm{M})\end{array}$ & 10.802 & $252134 \pm 0.0332$ & \\
\hline & $\begin{array}{c}\text { 6-hydroxy } \\
\text { chlorzoxazone }(50 \mu \mathrm{M})\end{array}$ & 5.2433 & $32907.333 \pm 0.5274$ & \\
\hline \multirow{4}{*}{$\begin{array}{l}\text { Isocratic elution } \\
\text { mode } \\
\left(60 \% \mathrm{H}_{2} \mathrm{O}+25 \%\right. \\
\text { Acetonitrile }+15 \% \\
\text { Methanol }) \\
\mathrm{T}=30{ }^{\circ} \mathrm{C}\end{array}$} & $\begin{array}{l}\text { Salicylic acid } \\
\quad(100 \mu \mathrm{M})\end{array}$ & 3.463 & $153602 \pm 0.2202$ & \multirow{4}{*}{$\begin{array}{l}\text { Good resolution } \\
\text { obtained between } \\
\text { four components. } \\
\text { (Difference } \\
\text { between } \\
\text { Phenacetin and } \\
\text { chlorzoxazone } \\
\text { peaks }=2.18 \mathrm{~min} \text { ) }\end{array}$} \\
\hline & Phenacetin $(50 \mu \mathrm{M})$ & 7.442 & $12399 \pm 0.7587$ & \\
\hline & $\begin{array}{l}\text { Chlorzoxazone } \\
\qquad(200 \mu \mathrm{M})\end{array}$ & 10.06 & $253038 \pm 0.0452$ & \\
\hline & $\begin{array}{c}\text { 6-hydroxy } \\
\text { chlorzoxazone } \\
(50 \mu \mathrm{M})\end{array}$ & 5.008 & $33648 \pm 0.6316$ & \\
\hline
\end{tabular}

Table A6 shows the variation of area peak, retention time of CYP2E1 compounds when the column Temperature increased from $25^{\circ} \mathrm{C}$ to $35^{\circ} \mathrm{C}$.

Overall, area peak, retention time remains unaffected for all CYP2E1 compounds when changing one of the HPLC parameters. Therefore, this method showed a robust methodology.

Table A6. Variation in area peak, retention time of each CYP2E1 compounds when changing the column temperature.

\begin{tabular}{|c|c|c|c|c|}
\hline $\begin{array}{l}\text { Mobile Phase } \\
\text { composition }\end{array}$ & $\begin{array}{l}\text { Compounds } \\
\text { present in the } \\
\text { sample }\end{array}$ & $\begin{array}{l}\text { Average Retention } \\
\text { time } \\
\text { (min) }\end{array}$ & $\begin{array}{l}\text { Average Area peak } \\
\quad(\text { Mean } \pm \text { Std) }\end{array}$ & Resolution \\
\hline \multirow{4}{*}{$\begin{array}{c}\text { Isocratic elution } \\
\text { mode } \\
\left(60 \% \mathrm{H}_{2} \mathrm{O}+25 \%\right. \\
\text { Acetonitrile }+15 \% \\
\text { Methanol }) \\
\mathrm{T}=25{ }^{\circ} \mathrm{C}\end{array}$} & $\begin{array}{l}\text { Salicylic acid } \\
\quad(100 \mu \mathrm{M})\end{array}$ & 3.425 & $153201.667 \pm 0.1842$ & \multirow{4}{*}{$\begin{array}{l}\text { Better resolution } \\
\text { obtained between } \\
\text { four components. } \\
\text { (Difference } \\
\text { between } \\
\text { Phenacetin and } \\
\text { chlorzoxazone } \\
\text { peaks = 3.0544 min) }\end{array}$} \\
\hline & Phenacetin $(50 \mu \mathrm{M})$ & 7.7476 & $12049.667 \pm 1.1991$ & \\
\hline & $\begin{array}{c}\text { Chlorzoxazone } \\
(200 \mu \mathrm{M})\end{array}$ & 10.802 & $252134 \pm 0.0332$ & \\
\hline & $\begin{array}{l}\text { 6-hydroxy } \\
\text { chlorzoxazone } \\
(50 \mu \mathrm{M})\end{array}$ & 5.2433 & $32907.333 \pm 0.5274$ & \\
\hline \multirow{4}{*}{$\begin{array}{c}\text { Isocratic elution } \\
\text { mode } \\
\left(60 \% \mathrm{H}_{2} \mathrm{O}+25 \%\right. \\
\text { Acetonitrile }+15 \% \\
\text { Methanol }) \\
\mathrm{T}=35^{\circ} \mathrm{C}\end{array}$} & $\begin{array}{l}\text { Salicylic acid } \\
\qquad(100 \mu \mathrm{M})\end{array}$ & 3.44933 & $154084.333 \pm 0.1215$ & \multirow{4}{*}{$\begin{array}{l}\text { Good resolution } \\
\text { obtained between } \\
\text { four components. } \\
\text { (Difference } \\
\text { between } \\
\text { Phenacetin and } \\
\text { chlorzoxazone } \\
\text { peaks }=2.309 \mathrm{~min} \text { ) }\end{array}$} \\
\hline & Phenacetin $(50 \mu \mathrm{M})$ & 7.199 & $12341.6667 \pm 0.5906$ & \\
\hline & $\begin{array}{l}\text { Chlorzoxazone } \\
\qquad(200 \mu \mathrm{M})\end{array}$ & 9.508 & $253184 \pm 0.0691$ & \\
\hline & $\begin{array}{l}\text { 6-hydroxy } \\
\text { chlorzoxazone } \\
(50 \mu \mathrm{M})\end{array}$ & 4.9353 & $34170 \pm 0.8637$ & \\
\hline
\end{tabular}




\section{References}

1. Sun, M.; Tang, Y.; Ding, T.; Liu, M.; Wang, X. Inhibitory effects of celastrol on rat liver cytochrome P450 1A2, 2C11, 2D6, 2E1 and 3A2 activity. Fitoterapia 2014, 92, 1-8. [CrossRef]

2. Wang, Y.; Wu, S.; Chen, Z.; Zhang, H.; Zhao, W. Inhibitory effects of cytochrome P450 enzymes CYP1A2, CYP2A6, CYP2E1 and CYP3A4 by extracts and alkaloids of Gelsemium elegans roots. J. Ethnopharmacol. 2015, 166, 66-73. [CrossRef]

3. Badyal, D.K.; Dadhich, A.P. Cytochrome P450 and drug interactions. Indian J. Pharmacol. 2001, 33, $248-259$.

4. Dumbreck, S.; Flynn, A.; Nairn, M.; Wilson, M.; Treweek, S.; Mercer, S.W.; Alderson, P.; Thompson, A.; Payne, K.; Guthrie, B. Drug-disease and drug-drug interactions: Systematic examination of recommendations in 12 UK national clinical guidelines. BMJ 2015, 350, 1-8. [CrossRef] [PubMed]

5. Takeda, T.; Hao, M.; Cheng, T.; Bryant, S.H.; Wang, Y. Predicting drug-drug interactions through drug structural similarities and interaction networks incorporating pharmacokinetics and pharmacodynamics knowledge. J. Cheminform. 2017, 9, 1-9. [CrossRef] [PubMed]

6. Murtaza, G.; Khan, M.Y.G.; Azhar, S.; Khan, S.A.; Khan, T.M. Assessment of potential drug-drug interactions and its associated factors in the hospitalized cardiac patients. Saudi Pharm. J. 2016, 24, 220-225. [CrossRef] [PubMed]

7. Sweeney, B.P.; Bromilow, J. Liver enzyme induction and inhibition: Implications for anaesthesia. Anaesthesia 2006, 61, 159-177. [CrossRef] [PubMed]

8. Lynch, T.; Price, A. The effect of cytochrome P450 metabolism on drug response, interactions, and adverse effects. Am. Fam. Physician 2007, 76, 391-396.

9. Dachineni, R.; Kumar, D.R.; Callegari, E.; Kesharwani, S.S.; Sankaranarayanan, R.; Seefeldt, T.; Tummala, H.; Bhat, G.J. Salicylic acid metabolites and derivatives inhibit CDK activity: Novel insights into aspirin's chemopreventive effects against colorectal cancer. Int. J. Oncol. 2017, 51, 1661-1671. [CrossRef] [PubMed]

10. Salhab, H.; Naughton, D.P.; Barker, J. Validation of an HPLC Method for the Simultaneous Quantification of Metabolic Reaction Products Catalysed by CYP2C11 Enzymes in Rat Liver Microsomes: In Vitro Inhibitory Effect of Salicylic Acid on CYP2C11 Enzyme. Molecule 2019, 24, 4294. [CrossRef] [PubMed]

11. Mafiadoc.com. Solvent Cut-off wavelengths-MAFIADOC.COM. 2011. Available online: https://mafiadoc. com/solvent-cut-off-wavelengths_597739701723dde28b57cfaf.html (accessed on 19 February 2020).

12. Shaikh, K.; Devkhile, A. Simultaneous Determination of Aceclofenac, Paracetamol, and Chlorzoxazone by RP-HPLC in Pharmaceutical Dosage Form. J. Chromatogr. Sci. 2008, 46, 649-652. [CrossRef] [PubMed]

13. Schelstraete, W.; Devreese, M.; Croubels, S. Storage stability study of porcine hepatic and intestinal cytochrome P450 isoenzymes by use of a newly developed and fully validated highly sensitive HPLC-MS/MS method. Anal. Bioanal. Chem. 2018, 410, 1833-1843. [CrossRef] [PubMed]

14. Bibi, Z. Retraction: Role of cytochrome P450 in drug interactions. Nutr. Metab. 2014. [CrossRef] [PubMed]

15. Hines, R.N.; McCarver, D.G. The ontogeny of human drug-metabolizing enzymes: Phase I oxidative enzymes. J. Pharmacol. Exp. Ther. 2002, 300, 355-360. [CrossRef] [PubMed]

16. Furge, L.L.; Guengerich, F.P. Cytochrome P450 enzymes in drug metabolism and chemical toxicology: An introduction. Biochem. Mol. Biol. Educ. 2006, 34, 66-74. [CrossRef] [PubMed]

17. Collom, S.; Laddusaw, R.; Burch, A.; Kuzmic, P.; Perry, M.; Miller, G. CYP2E1 Substrate Inhibition. J. Biol. Chem. 2007, 283, 3487-3496. [CrossRef] [PubMed]

18. Hodges, R.E.; Minich, D.M. Modulation of Metabolic Detoxification Pathways Using Foods and Food-Derived Components: A Scientific Review with Clinical Application. J. Nutr. Metab. 2015. [CrossRef] [PubMed]

19. Li, H.; Letcher, R.J. A high-performance-liquid-chromatography-based method for the determination of hydroxylated testosterone metabolites formed in vitro in liver microsomes from gray seal (Halichoerus grypus). J. Chromatogr. Sci. 2002, 40, 397-402. [CrossRef] [PubMed]

Sample Availability: Samples of the compounds are available from the authors.

(C) 2020 by the authors. Licensee MDPI, Basel, Switzerland. This article is an open access article distributed under the terms and conditions of the Creative Commons Attribution (CC BY) license (http://creativecommons.org/licenses/by/4.0/). 